\title{
Preferred use of bacteria over phytoplankton by deep-sea nematodes in polar regions
}

\author{
Jeroen Ingels ${ }^{1, *}$, Pieter Van den Driessche ${ }^{1}$, Ilse De Mesel $^{2}$, Sandra Vanhove ${ }^{3}$, \\ Tom Moens ${ }^{1}$, Ann Vanreusel ${ }^{1}$
}

\author{
${ }^{1}$ Marine Biology Department, Ghent University, Krijgslaan 281 S8, 9000 Ghent, Belgium \\ ${ }^{2}$ Institute for Marine Resources \& Ecosystem Studies, PO Box 77, 4400 AB Yerseke, The Netherlands \\ ${ }^{3}$ The International Polar Foundation, Tweestationstraat 120A, Brussels 1070, Belgium
}

\begin{abstract}
The present study explored the selective feeding properties of Antarctic and Arctic deep-sea nematodes within an experimental setup. Nematodes are assumed to play an important role in the carbon flux within the polar bathyal food webs, but knowledge about their natural diets is limited. For the first time, deep-sea multicore sediment samples from both polar regions were incubated aboard research vessels with either ${ }^{13} \mathrm{C}$-labelled bacteria or diatoms to determine whether the nematode community prefers freshly settled phytodetritus to a bacterial food source. The cores were collected at 2112 to $2400 \mathrm{~m}$ water depth and incubated onboard for 1, 3 and $6 \mathrm{~d}$ in the Arctic (Hausgarten) and for 1,7 and $14 \mathrm{~d}$ in Antarctica (Kapp Norvegia). Natural carbon isotope signals of nematodes and organic sedimentary carbon showed a clear average offset $(+3.2 \%)$. The contribution of bacteria to the diet of nematodes explained this ${ }^{13} \mathrm{C}$ offset and observed natural ${ }^{13} \mathrm{C}$ isotopic signatures. The nematodes showed a clear, relatively rapid (maximum at 6 to $7 \mathrm{~d}$ ) and significant selective response to the pulse of ${ }^{13} \mathrm{C}$ enriched bacteria in surface sediments of both regions. This indicated that bacteria were preferred over fresh phytoplankton as a carbon source for both Arctic and Antarctic deep-sea nematode communities. The results also suggest that bacteria may provide a path through which unused detritus may enter the traditional metazoan food web by microbial reworking of organic matter. At the same time, uptake rates of nematode communities were minimal, which suggests the contribution of nematodes to benthic mineralisation of freshly deposited organic matter may be limited in deep polar seas.
\end{abstract}

KEY WORDS: Deep-sea nematodes $\cdot$ Bacteria $\cdot$ Phytoplankton $\cdot$ Polar regions

\section{INTRODUCTION}

In the deep sea, benthic ecosystems are sustained largely by phytodetritus settling from the euphotic zone, which occurs mainly during spring/early summer phytoplankton blooms (Gooday 2002). In the Arctic and Antarctic these phytoplankton blooms are predominated by diatoms (Bathmann et al. 1997, Fogg 1998, Morata et al. 2008). Consequently, sedimenting aggregates contain not only a high proportion of planktonic, but also sympagic (retained in ice) diatoms (Bodungen et al. 1986, Graf et al. 1995), thus providing a substantial food supply for the benthos.
Next to diatoms, bacterioplankton is another key component of euphotic primary productivity, corresponding to $11 \%$ of total primary production in spring (Sullivan et al. 1990) and up to $76 \%$ in autumn (Cota et al. 1990) at the marginal ice zone of the Weddell-Scotia Sea, and as such, they may also contribute substantially to the food supply of the benthos. Downward bentho-pelagic coupling appears to be particularly efficient in the Arctic and Antarctic (Smith et al. 2006, Morata et al. 2008, Tamelander et al. 2008), especially at marginal ice zones, which have been identified as regions of increased phytoplankton biomass, primary productivity (Fogg 1998) 
and bacterial activity (Sullivan et al. 1990). Benthic bacterial populations in Antarctic sediments can reach very high abundances (Novitsky 1987, Karl \& Novitsky 1988) constituting another potentially abundant food supply for the benthos. Both diatoms and bacteria have been found to be an important food source for the free-living nematodes in shallow-water benthic environments (Moens \& Vincx 1997). Information on nematode food sources in the Arctic and Antarctic is limited and for the deep sea there is a general lack of knowledge about which specific foods sustain the nematode communities. However, considering the importance of diatoms in the Antarctic and Arctic euphotic waters and their subsequent export to the deep-sea floor, along with the high pelagic and benthic bacterial productivity in these regions, both diatoms and bacteria may constitute important food sources for nematodes.

Nematodes are the most abundant metazoan component of the meiobenthos (32 to $1000 \mu \mathrm{m}$ ) in the deep sea and their numerical importance increases with water depth, as is reflected in their often high standing stocks (Heip et al. 1985, Soltwedel 2000). They are also characterised by relatively high reproductive capacities and metabolic rates, and because of their assumed intermediate trophic position they can play a key role in the transfer of organic matter (OM) within benthic food webs (Graf 1989, Danovaro et al. 1999a). Compared with other deep-sea regions, the Arctic and Antarctic deep-sea nematode communities attain higher or similar densities during summer (Herman \& Dahms 1992, Vanhove et al. 1995, 1999) for which food input is probably one of the main structuring factors, especially since nematodes show a strong dependence on food availability (Vanhove et al. 1999, Soltwedel 2000). However, while meiobenthos in shallow-water environments show rapid uptake of phytodetritus derived food input, deep-sea meiobenthos responses tend to be more variable (Moens et al. 2007 and references therein). Field observations on deep-sea, short-term benthic response to OM deposition show that foraminifera and bacteria respond rapidly (Moodley et al. 2002, Witte et al. 2003a), whilst nematode community responses remain inconsistent.

Nematodes are capable of consuming a broad range of microbial food and nonliving detrital material and may specialise on, or have preferences for, different types of food resources (Moens \& Vincx 1997 and references therein). Nematode specimens are generally identified as 1 of 4 different feeding guilds following the classification of Wieser (1953) based on buccal cavity and pharyngeal morphology. Selective deposit feeders (1A group) have a minute, toothless buccal cavity, restricting them to consuming small food parti- cles, as well as bacteria. The nonselective deposit feeders (1B) are characterised by a larger, toothless buccal cavity that allows them to feed on larger particles in a more nonselective or more general fashion compared with the selective deposit feeders. The epistratum feeders (2A) have a large buccal cavity with 1 or several teeth that they use to scrape off food particles from sediment grains or other hard substrates. Predatory and scavenging nematodes (2B) are characterised by having a large mouth and buccal cavity armed with large teeth, denticle bands and/or buccal armatures, which allow them to feed on other nematodes and meiofauna. So nematodes may swallow entire diatoms, rasp off microbial coatings around foraminiferal tests, or ingest bacteria and other organic particles from sediment grains. Accordingly, changes in nematode composition and abundances have been associated with planktonic foraminiferal deposition and protozoan biomass (Levin 1991, Vanreusel et al. 1995, Moodley et al. 1997, Danovaro et al. 1999b). Furthermore, nematodes may ingest microalgal detritus and associated bacteria and/or show selective uptake of these food sources (Tietjen \& Lee 1973, Jensen 1987). Therefore, there is a range of potential food sources for free-living nematodes and these may be consumed selectively.

Unfortunately, detailed information on the feeding ecology and trophic position of nematodes in deepsea environments is lacking. Yet, because of the ubiquitous distribution of nematodes and their high abundances, they can be analysed and experimentally manipulated on relatively small spatial scales with sufficient replication. Thus, nematodes present opportunities for logistically feasible analyses of foodweb structure and dynamics (Carman \& Fry 2002). Interpretation of deep-sea nematode feeding behaviour is generally based on the morphological classification of Wieser (1953), but real empirical evidence that documents the feeding strategies of deep-sea nematodes is lacking and hampers proper assessment of the position of nematodes in benthic food webs (Moens et al. 2005). The addition of an external labelled carbon source offers the opportunity to study the dynamics of the benthic response. The use of ${ }^{13} \mathrm{C}$ labelled food sources as a tracer of labile carbon (pulse-chase approach) has proven to be a powerful tool to follow the fate of fresh OM entering the sediments (Moodley et al. 2005). However, small organisms such as deep-sea meiobenthos have been the subject of relatively few stable isotope studies, primarily because deep-sea meiofauna have low biomass and large numbers of individuals must be collected to obtain sufficient material for analysis. Despite efforts to reduce the biomass needed for a reliable analysis (Carman \& Fry 2002), this require- 
ment still hampers trophic research on deep-sea nematodes at species and feeding group levels.

To gain insight into the potential food sources and response time of deep-sea nematodes of the Arctic and Antarctic benthic ecosystems, 2 in vitro ${ }^{13} \mathrm{C}$ pulsechase experiments were conducted at the community level for the first time in these deep-sea regions. By following the nematode community's response to a deposition of 2 types of labelled OM (pelagic diatoms and benthic bacteria, 2 naturally recurrent food sources) along the vertical sediment profile (0 to 1 and 1 to $2 \mathrm{~cm}$ ) and through time, the ability and selectivity of the nematodes to use freshly settled OM was assessed. In addition, the experiments allowed us to investigate the importance of settled phytoplankton to the nematode community in both the Arctic and Antarctic ice margin zones compared with an alternative food source (in this case benthic bacteria, which are of considerable importance in the areas investigated).

\section{MATERIALS AND METHODS}

Study sites. During the Antarctic ANDEEP III campaign (ANTXXII/3, 21 January to 6 April 2005, Fahrbach 2006) sediment samples were taken aboard the RV 'Polarstern', using a Barnett multicorer (MUC, Barnett et al. 1986) equipped with 12 core tubes hav- ing an internal diameter of $57 \mathrm{~mm}$, equivalent to a $25.5 \mathrm{~cm}^{2}$ surface area. In total 27 cores were collected over 3 replicate deployments off Kapp Norvegia (Stn AA, 2112 m water depth, Fig. 1, Table 1). These were used for the pulse-chase experiment and other biotic and abiotic analyses. In the Arctic, the Hausgarten station (Stn A, $2400 \mathrm{~m}$ water depth, Fig. 1, Table 1) was sampled during the German/French Arctic cruise AWI-VIC/Ifremer (13 to 30 September 2005) aboard RV 'l'Atalante', following an identical strategy as in the Antarctic. However, for this station only 2 replicate sediment cores were used for biotic and abiotic analyses. An overview of the distribution of the core samples for the different types of treatments and analyses is given in Fig. 2.

Meiofauna. For meiofauna community analysis, 3 and 2 replicate cores at Stns AA and A, respectively, were subdivided into 6 slices ( 0 to 1,1 to 2,2 to 3,3 to 4,4 to 5 and 5 to $10 \mathrm{~cm}$ ) and preserved in boraxbuffered $4 \%$ formalin. These cores were then processed further in the laboratory to retrieve the meiofauna fraction. For this study, we only focussed on the upper $2 \mathrm{~cm}$ since up to $80 \%$ of the meiofauna is confined to this sediment depth range (Vanhove et al. 1998) and low nematode numbers in the deeper layers preclude acquiring the minimum amount required for a reliable analysis. The top 2 sediment layers were rinsed separately over a column of 32 and $1000 \mu \mathrm{m}$

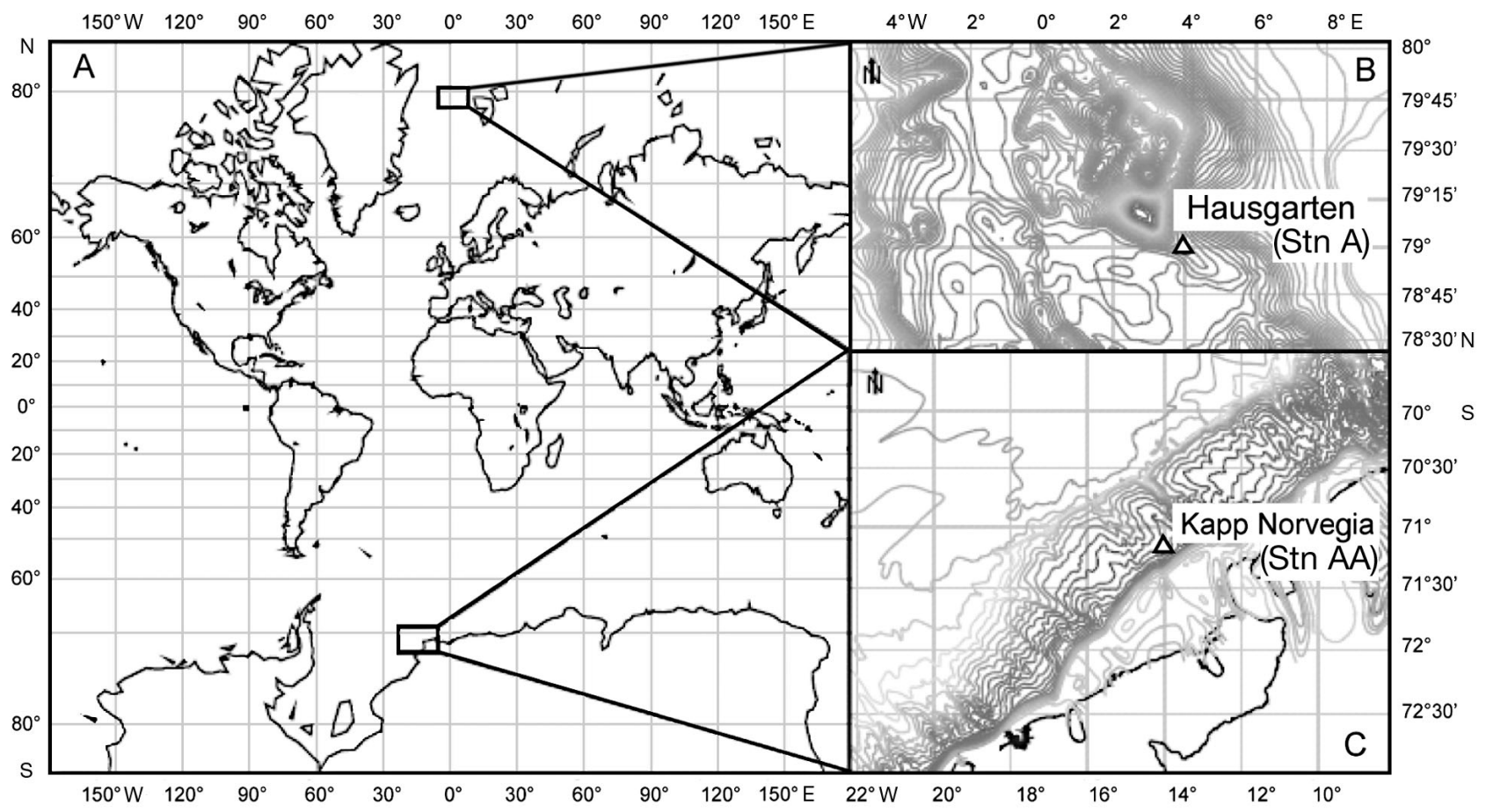

Fig. 1. Sites where samples were obtained for analysis and experiments. (A) Global map indicating locations of the 2 study areas. (B) Hausgarten site in the Arctic (Stn A; 2400 m water depth). (C) Kapp Norvegia site in Antarctica (Stn AA; 2112 m water depth). Continous black line: edge of ice shelf. Grey lines: depth contours 
Table 1. Station information and environmental variables (0 to 1 and 1 to $2 \mathrm{~cm}$ sediment depth) for the 2 stations Kapp Norvegia (Stn AA) and Hausgarten (Stn A). Values are mean \pm SD. Chl a: chlorophyll a; CPE: chloroplastic pigment equivalents (sum of chl $a$ and phaeopigments); Chl a:phaeo: ratio of chl a to phaeopigments; TOC: total organic carbon; N: nitrogen; C:N: ratio of molar carbon to nitrogen; MUC: multicorer; nd: no data

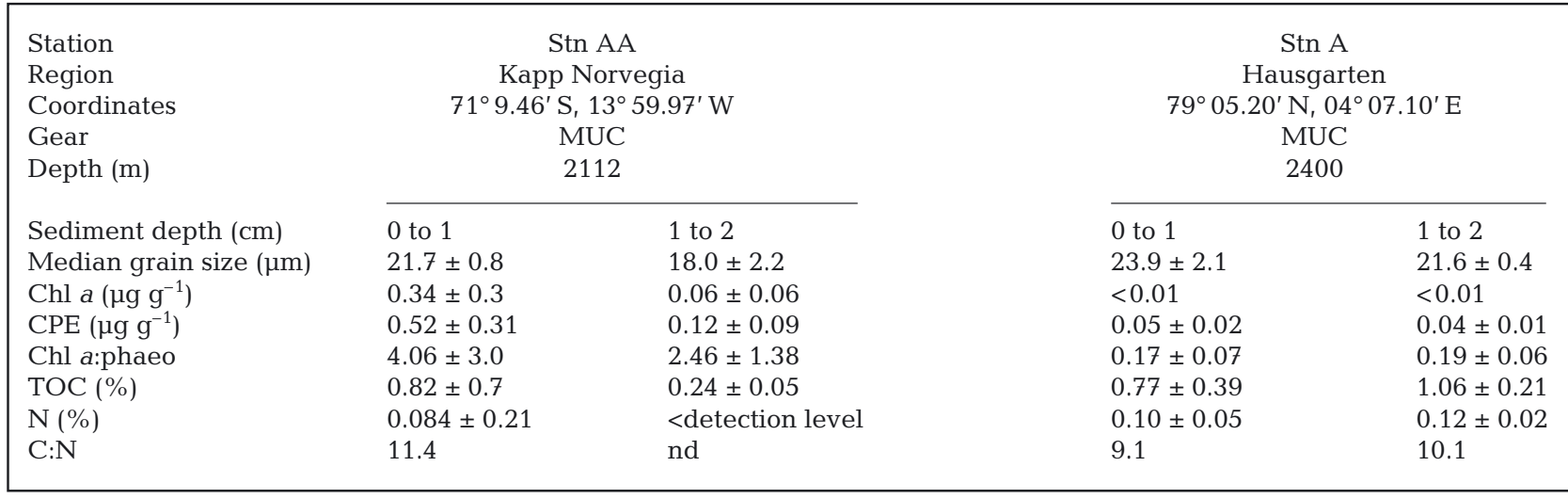

mesh sieves and centrifuged 3 times with the colloidal silica gel Ludox HS before staining with Bengal Rose (Heip et al. 1985, Vincx 1996). The meiofauna was then counted and identified at higher taxon levels under a stereoscopic microscope following the methods of Higgins \& Thiel (1988).

Environmental variables. At each station, 3 replicate cores were retrieved and kept at $-20^{\circ} \mathrm{C}$ for granulometric and biogeochemical analyses (chloroplastic pig-
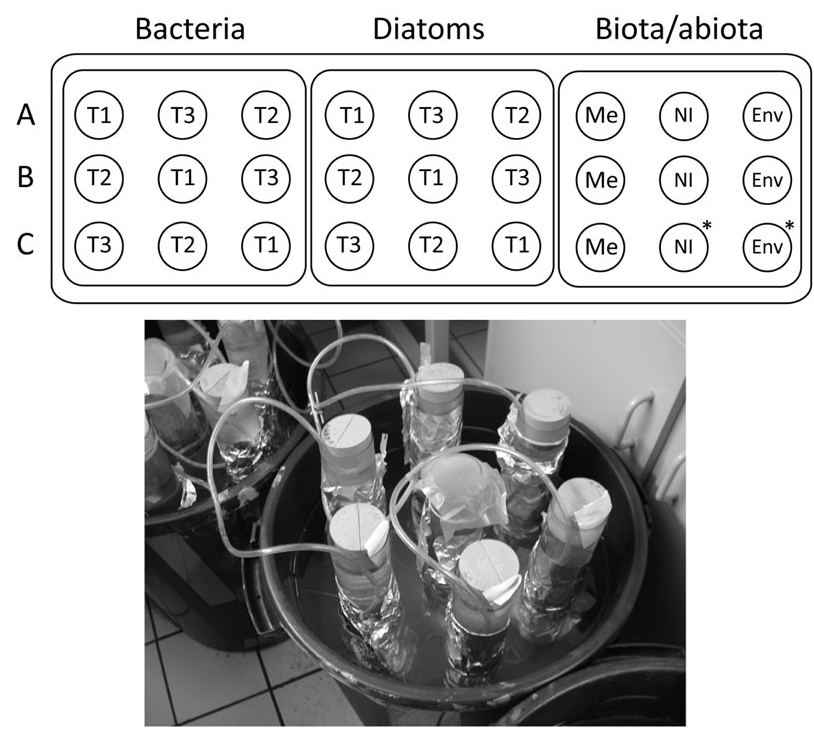

Fig. 2. Diagram illustrating the fate of core samples from each site. Row A to C: 3 different multicorer (MUC) deployments. Bacteria, diatoms: cores incubated with labelled, freeze-dried bacteria, or diatoms, respectively. Biota/abiota: cores for analysis of meiofauna community (Me), natural ${ }^{13} \mathrm{C}$ isotopes (NI), and environmental variables (Env). Photograph: experimental setup under shipboard laboratory conditions. T1 to T3 represent incubation times, or times when the samples were taken during the experiments. $\left({ }^{*}\right)$ : these cores were not available at the Arctic station (Hausgarten) ment equivalents [CPE], organic carbon [OC] and nitrogen $[\mathrm{N}]$ content and bulk sediment natural ${ }^{13} \mathrm{C}$ isotope signatures). The grain-size distribution of the 4 to $800 \mu \mathrm{m}$ fraction in the sediments was measured using a Coulter Counter LS 100 Particle Size Analyser and classified according to Wentworth (1922). Total sedimentary $\mathrm{OC}$ and $\mathrm{N}$ content was determined with a Carlo Erba elemental analyser on freeze-dried and homogenised sediment samples after acidification with dilute $\mathrm{HCl}$ to eliminate carbonates $(1 \% \mathrm{HCl}$ was repeatedly added to the samples on a heated $\left[80^{\circ} \mathrm{C}\right]$ metal multi-well plate at $1 \mathrm{~h}$ intervals until decarbonation was complete; a fume cupboard was used to enhance dehydration before sample analysis). To analyse chloroplastic pigments, sediment samples were freeze-dried and homogenised, after which the pigments were extracted in $90 \%$ acetone, separated using reverse phase HPLC, and measured with a Gilson fluorescence detector according to Wright \& Jeffrey (1997). As a measure of freshness of the phytodetritus we applied the ratio between chlorophyll a ( $\mathrm{chl} \mathrm{a}$ ) content and the phaeopigments (chl a breakdown products, here referred to as 'phaeo'). For natural ${ }^{13} \mathrm{C}$ isotope analysis of the sediment, 20 to $40 \mathrm{mg}$ aliquots of dried, ground and homogenised sediment were weighed and then acidified in preglown (heated overnight at $550^{\circ} \mathrm{C}$ to eliminate $\mathrm{C}$ contamination) silver cups with dilute $\mathrm{HCl}$ to eliminate the carbonate fraction. The cups were subsequently pinch-closed and stored in multi-well microtitre plates under dry atmosphere until analysis.

Cultivation and ${ }^{13} \mathrm{C}$ enrichment of food sources. Pelagic diatoms (Thalassiosira rotula, average cell size: $8 \mu \mathrm{m}$ diameter) were cultured axenically in f/2 medium (Guillard 1975) contained in sterile Erlenmeyer flasks at 18 to $20^{\circ} \mathrm{C}$ with a $12 \mathrm{~h}$ light: $12 \mathrm{~h}$ dark period. Diatom enrichment occurred through addition 
of $5 \mathrm{ml} \mathrm{NaH}{ }^{13} \mathrm{CO}_{3}\left({ }^{13} \mathrm{C}, 99 \%\right.$, Cambridge Isotope Laboratories; $336 \mathrm{mg} 100 \mathrm{ml}^{-1}$ Milli-Q $\mathrm{H}_{2} \mathrm{O}$ ) per $100 \mathrm{ml} / 2$ culture medium during growth. After labelling, the medium was washed away and the diatoms were isolated by triple centrifugation (5 min at $3500 \mathrm{rpm}$ ), freeze-dried and stored under dry atmosphere before experimental use. This labelling technique resulted in a $\delta^{13} \mathrm{C}$ increase from $-21.1 \%$ to $14000 \%$, which implied $14.4 \%$ of their carbon was ${ }^{13} \mathrm{C}$.

Benthic bacteria were isolated from shallow water North Sea samples off the Belgian coast. Cultivation occurred by sequential use of rich and poor broth media, based on artificial seawater (ASW; salinity of 35, Moens \& Vincx 1998). In a first phase, bacteria were grown to high abundance in liquid rich broth medium prepared with $0.4 \mathrm{~g} \mathrm{l}^{-1}$ bacto beef extract and $0.66 \mathrm{~g} \mathrm{l}^{-1}$ bacto peptone. They were then harvested and rinsed through repeated centrifugation in ASW, and then resuspended in a diluted, poor broth medium prepared with concentrations of beef extract and peptone that were 10 times lower than those used in the high broth medium. ${ }^{13} \mathrm{C}$-glucose (U- ${ }^{13} \mathrm{C} 6,99 \%$ ) was added to the poor broth medium at $1 \mathrm{~g} \mathrm{l}^{-1}$; bacteria were then harvested and rinsed through repeated centrifugation in ASW, freeze-dried and stored under dry atmosphere until use. $\delta^{13} \mathrm{C}$ of the labelled bacteria was ca. $150000 \%$, which implied that two-thirds of their carbon was ${ }^{13} \mathrm{C}$.

Pulse-chase experiments. The execution of the Arctic and Antarctic experiments followed an identical protocol, except for the duration of the experiment, which allowed for a comprehensive comparison of both. At both locations, 18 undisturbed sediment cores $(20$ to $30 \mathrm{~cm}$ ) from 3 MUC deployments were randomly assigned to the 2 different treatments (Fig. 2). The incubations were done shipboard in a darkened, temperature-controlled room at $-1^{\circ} \mathrm{C}$, approaching the in situ habitat temperature, with $20 \mathrm{~cm}$ of ambient original bottom water covering the sediment surface. To minimise temperature fluctuations and avoid oxygen exhaustion, the cores were wrapped in aluminium foil and kept in seawater in a large receptacle whilst the core water column was aerated during the whole incubation period. After $1 \mathrm{~d}$ of acclimatisation at the start of the experiment, the cores were enriched with freezedried ${ }^{13} \mathrm{C}$-labelled diatoms (Thalassiosira rotula) or benthic bacteria (unidentified strains), mimicking a flux of $1000 \mathrm{mg} \mathrm{C} \mathrm{m}^{-2}$ (= $2.55 \mathrm{mg} \mathrm{C} \mathrm{core}^{-1}$ ) to the sediment. This C-flux is translated into ca. 11.1 and $8 \mathrm{mg}$ dry weight of diatoms and bacteria, respectively. At Stn A, the particulate organic carbon flux was measured at about $300 \mathrm{~m}$ water depth during a $5 \mathrm{yr}$ period (2000 to 2005), indicating an average flux of ca. 36 to $88 \mathrm{mg} \mathrm{m}^{-2} \mathrm{~d}^{-1}$ (Bauerfeind et al. 2009). Off Kapp Norvegia, a similar organic carbon flux of ca. $36 \mathrm{mg}$ $\mathrm{m}^{-2} \mathrm{~d}^{-1}$ was measured at $630 \mathrm{~m}$ water depth during the summer period (Bathmann et al. 1991). Therefore, the amount of labelled material added is equivalent to the natural downward organic carbon flux of about 11 to $28 \mathrm{~d}$. However, this estimate does not take into account the water depth differences between where the fluxes were measured and the seabed, so the amount of organic carbon reaching the sea floor at 2112 and $2400 \mathrm{~m}$ water depths may be considerably less. After freeze-drying, the diatoms and bacteria were washed, dried, weighed, and stored under dry atmosphere in the laboratory. On board, the preweighed aliquots of both enriched food sources were resuspended in seawater and refrozen as a small cube of ice around a sterile, firm metal thread. The thread served as a handle to bring the enriched food as close as possible to the sediment surface, to avoid disturbance and to spread it evenly over the sediment surface within the core. This technique proved efficient since the diatoms and bacteria settled rapidly and formed a distinct, relatively evenly spread layer that was visible on the sediment surface within $10 \mathrm{~min}$. From each deployment, 3 cores were treated with bacteria and 3 cores with diatoms, which provided 3 replicates for each treatment and sampling time for both locations. The incubated cores were sampled after 1,7 or $14 \mathrm{~d}$ in the Antarctic and after 1, 3 or $6 \mathrm{~d}$ in the Arctic. The duration of the experiments was based on the survival of the deep-sea nematodes onboard, which was regularly assessed with a stereomicroscope, and restrictions on ship time availability. After each incubation period, the top $2 \mathrm{~cm}$ of 3 replicate cores for each of the 2 treatments were sliced $1 \mathrm{~cm}$ thick and stored in Petri dishes at $-20^{\circ} \mathrm{C}$ for stable isotope analysis of the treated nematode community. To investigate the natural ${ }^{13} \mathrm{C}$ isotopic abundance of the nematode community, the top $2 \mathrm{~cm}$ of 3 and 2 replicate sediment cores for Stns AA and A, respectively, were sliced and frozen at $-20^{\circ} \mathrm{C}$ until further analysis.

Isotope analysis and data treatment. In the laboratory, the 0 to 1 and 1 to $2 \mathrm{~cm}$ depth slices of each experimental sediment core were decanted into a $5 \mathrm{l}$ jar through a $125 \mu \mathrm{m}$ mesh sieve to retrieve the larger nematode specimens and, hence, reduce picking effort whilst maintaining sufficient biomass for isotope analysis. After the sediment had precipitated, the still natant meiofauna were poured off onto the sieves. This procedure was repeated 10 times, after which the meiofauna was stored in Milli-Q water and immediately processed. Hence, there was no exogenous carbon contamination from any chemical preservatives, elutriation gels or dyes. Nematodes were handpicked with a fine sterile needle, rinsed twice in Milli-Q water to remove adhering particles and finally transferred to a drop of Milli-Q water in $2.5 \times 6 \mathrm{~mm}$ aluminium cups. 
The cups had been preheated at $550^{\circ} \mathrm{C}$ to remove any contaminating OC. The aluminium cups with nematodes were oven-dried overnight at $60^{\circ} \mathrm{C}$, pinched closed and stored in airtight multi-well microtiter plates. A minimum of 70 nematodes per sample, depending on crude biomass estimates based on observations of length and width of selected specimens, were picked out to ensure sufficient biomass for 1 reliable isotope analysis. Here, carbon was conservatively estimated at $10 \%$ of nematode wet weight (Heip et al. 1985). Nematode samples for natural C isotope analysis received identical preparatory treatment as did the experimental samples. The carbon isotopic composition of the samples was determined with an elemental analyser (PDZ Europa ANCA-GSL) interfaced to an isotope ratio mass spectrometer (PDZ Europa 20-20, Sercon; University of California Davis).

All nematode isotope data were corrected with the results from analysed, empty aluminium control cups. Uptake of ${ }^{13} \mathrm{C}$ is reflected as excess (above natural abundance) ${ }^{13} \mathrm{C}$ and is expressed as total uptake in the sample $(I)$ in micrograms of $\mathrm{C}$ and as specific uptake $\left(\Delta \delta^{13} \mathrm{C}=\delta^{13} \mathrm{C}_{\text {sample }}-\delta^{13} \mathrm{C}_{\text {control }}\right) \cdot \delta^{13} \mathrm{C}_{\text {sample }}$ is calculated as $\left[\left(R_{\text {sample }}-R_{\mathrm{VPDB}}\right) / R_{\mathrm{VPDB}}\right] \times 10^{3}$ with $R_{\mathrm{VPDB}}=$ 0.0112372 , which is the carbon isotope ratio of the Vienna Pee Dee Belemnite standard, and $R_{\text {sample }}=$ $\left[\left(\delta^{13} \mathrm{C}_{\text {sample }} / 1000\right)+1\right] \times R_{\mathrm{VPDB}}($ Craig 1957$)$. The fractional abundance of ${ }^{13} \mathrm{C}(F)$ equals $R /(R+1)$ and is used to calculate the excess ${ }^{13} \mathrm{C}(E)$ in the samples, which is the difference between the ${ }^{13} \mathrm{C}$ fraction of the sample $\left(F_{\text {sample }}\right)$ and the ${ }^{13} \mathrm{C}$ fraction of the control $\left(F_{\text {control }}\right)$, i.e. $E=F_{\text {sample }}-F_{\text {control. }}$. Data are reported as the average of replicates with SD. $I$ is calculated as the product of $E$ and $\mathrm{C}$ weight $(\mu \mathrm{g})$ of the nematode sample as produced by the isotope analysis, and was then recalculated as total core $\mathrm{C}$ uptake ( $\mu \mathrm{g} \mathrm{C}$ core $^{-1}$ ).

To investigate the significance of the uptake values, the nonparametric Mann-Whitney $U$-test for independent samples was applied using Statistica 5.5.

\section{RESULTS}

\section{Environmental variables}

A summary of environmental variables is given in Table 1. Sediments at Stn AA were dominated by fine silts (4 to $38 \mu \mathrm{m}$ ) with smaller fractions of clay and fine sand $(<4 \mu \mathrm{m}$ and 63 to $250 \mu \mathrm{m}$, respectively). Sediments in Stn A had similar texture in both sediment strata, but showed higher amounts of fine to medium sands (63 to $500 \mu \mathrm{m})$ than did the sediments from Stn AA. In addition, many sponge spicules were observed in the surface layers of both the Arctic and Antarctic stations. At Stn AA, OC content was higher at the sur- face compared with the subsurface, while no such difference was found at Stn A (Table 1). The C:N ratios were similar for both stations, ranging between 9.1 and 11.4 , and reflect the presence of relatively degraded marine OM and/or terrigenous input of OM (Killops \& Killops 2005, Emerson \& Hedges 2008). CPE values for the Antarctic were significantly $(\mathrm{p}<0.05)$ higher than those for the Arctic, where pigment concentrations neared the detection limit (Table 1). However, CPE content was highly variable among replicate samples, indicating patchy phytodetritus availability. The chl a:phaeo ratios (Table 1) revealed that the Antarctic superficial phytodetritus was fresher than in the Arctic and that superficial OM was of higher quality than deeper in the sediment. The latter was not the case in the Arctic, where 'freshness' values were similar for both sediment layers.

\section{Meiofauna}

A total of 16 meiofauna taxa were observed, 13 at Stn AA and 12 at Stn A. At Stn A, meiofauna densities averaged $434 \pm 5$ and $372 \pm 10$ individuals (ind.) $10 \mathrm{~cm}^{-2}$ for the 0 to 1 and 1 to $2 \mathrm{~cm}$ sediment layers, respectively. At Stn AA, meiofauna densities were higher at the surface ( 0 to $1 \mathrm{~cm}, 645 \pm 9$ ind. $10 \mathrm{~cm}^{-2}$ ), whilst densities in the subsurface layer $(1$ to $2 \mathrm{~cm}$ ) attained $346 \pm 18$ ind. $10 \mathrm{~cm}^{-2}$. Nematoda strongly dominated the community, comprising 91.1 and $93.3 \%$ of total meiofauna abundance $(0$ to $2 \mathrm{~cm}$, no. ind. $10 \mathrm{~cm}^{-2}$ ) at Stns AA and A, respectively. Other subdominant taxa included Copepoda, Polychaeta, Oligochaeta and Ostracoda $(>1 \%)$. Some taxa appeared only sporadically, suggesting microscale patchiness or bias due to a small sample surface. For more detailed information on meiofauna community structure for the 2 study sites, we refer to Vanhove et al. $(1995,1998)$ and Hoste et al. (2007) for the Antarctic and Arctic, respectively.

\section{${ }^{13} \mathrm{C}$ offset between sediment $\mathrm{OM}$ and nematodes}

The natural $\delta^{13} \mathrm{C}$ signals of nematodes $\left(\delta^{13} \mathrm{C}_{\text {nema }}\right)$ and bulk sedimentary OM $\left(\delta^{13} \mathrm{C}_{\text {sed }}\right)$ at Stns AA and A are shown in Fig. 3. The $\delta^{13} \mathrm{C}_{\text {sed }}$ signatures at Stn AA (-25.2 $\pm 0.1 \%$ o) were consistently more depleted than those at Stn A $(-22.4 \pm 0.1 \%)$, but remained constant over the vertical sediment profile (Fig. 3). The nematode communities at Stn AA were also more depleted than at Stn A with average $\delta^{13} C_{n e m a}$ values of $-22.4 \pm 1.1 \%$ and $-18.8 \pm 0.5 \%$, respectively. At both stations, no significant $\delta^{13} \mathrm{C}_{\text {nema }}$ differences were observed with sediment depth. 


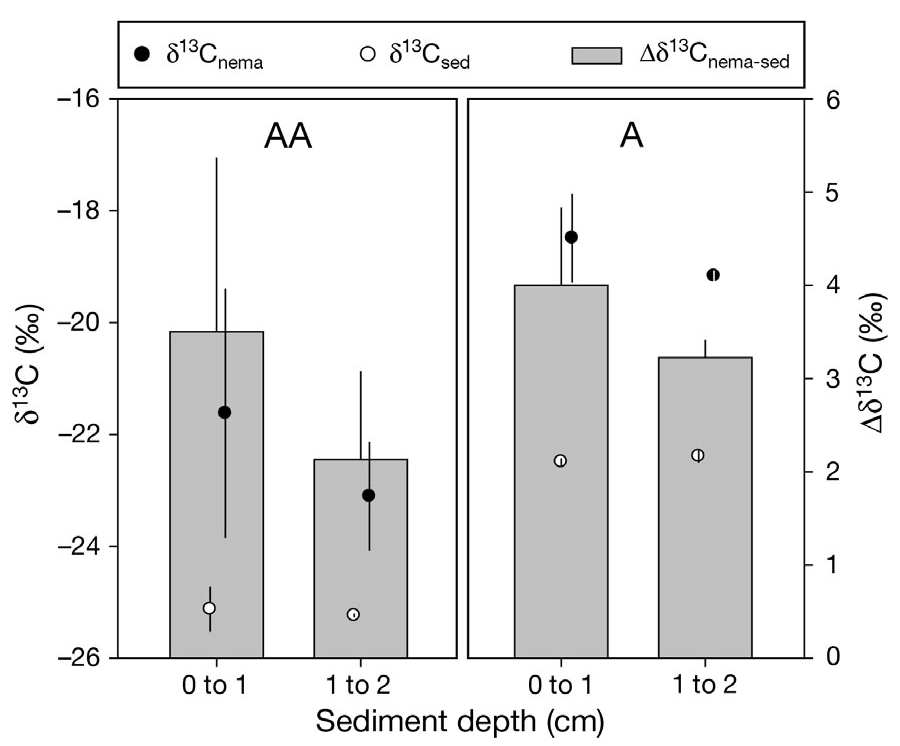

Fig. 3. Natural ${ }^{13} \mathrm{C}$ isotope signatures $\left(\delta^{13} \mathrm{C}\right)$ for sedimentary organic carbon $\left(\delta^{13} \mathrm{C}_{\text {sed }}\right)$ and nematode community (ca. 70 individuals, $\delta^{13} \mathrm{C}_{\text {nema }}$ ). The isotopic shift between $\delta^{13} \mathrm{C}_{\text {nema }}$

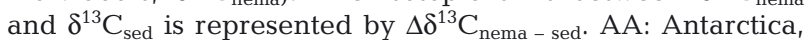
Stn $A_{A} ; A$ : the Arctic, Stn $A_{;}$values are mean $\pm S D$

On average a $\Delta \delta^{13} \mathrm{C}$ isotopic offset of $+3.2 \pm 0.8 \%$ o was found between the $\delta^{13} \mathrm{C}_{\text {nema }}$ and the ${ }^{13} \mathrm{C}_{\text {sed }}$ signals (average value of all replicates from both stations and sediment layers). At both stations, this isotopic shift appeared more clearly in the surface layer (+3.8\%o) compared with the 1 to $2 \mathrm{~cm}$ sediment layer $(+2.7 \%$ ).

\section{Enrichment experiment}

The uptake values ( $I=$ total core $\mathrm{C}$ uptake) of the nematode community in the Antarctic and Arctic experiment are presented in Fig. 4. For both stations, assimilation of ${ }^{13} \mathrm{C}$-enriched bacteria was significant $(\mathrm{p}$ $<0.05)$ for all incubation times in the upper centimetre of the sediment (Fig. 4). However, the replicate $\delta^{13} \mathrm{C}$ and $I$ values were highly variable at times (high SD). No consistent ${ }^{13} \mathrm{C}$ incorporation was observed for the 1 to $2 \mathrm{~cm}$ layer and diatom-treated samples, although, for 2 replicated sets of these samples, the $\delta^{13} \mathrm{C}$ uptake values showed significant differences with natural background values as indicated in Fig. 4. In general, I uptake values from the surface samples were significantly $(\mathrm{p}<0.05)$ higher for nematodes on a bacterial diet compared with those on a diatom diet, which suggests bacteria is a preferred food source over diatoms for the deep-sea nematode community.

At Stn AA, the nematode community showed a significant $(\mathrm{p}<0.05)$ average uptake $(I)$ after only $1 \mathrm{~d}$ of incubation $\left(19.19 \times 10^{-3} \mu \mathrm{g} C\right.$ core $\left.^{-1}\right)$, with a small increase after $7 \mathrm{~d}\left(28.60 \times 10^{-3} \mu \mathrm{g} \mathrm{C}\right.$ core $\left.^{-1}\right)$, and a subsequent decrease by Day $14\left(24.26 \times 10^{-3} \mu \mathrm{g} \mathrm{C} \mathrm{core}{ }^{-1}\right)$. However, no significant $I$ differences occurred between incubation times because of the high replicate variability.

At Stn A, incorporation of the bacterial label in the nematode community was more gradual: low $I$ values after Day $1\left(18.73 \times 10^{-4} \mu \mathrm{g} \mathrm{C}\right.$ core $\left.^{-1}\right)$, increased uptake after Day $3\left(25.21 \times 10^{-4} \mu \mathrm{g} \mathrm{C}\right.$ core $\left.^{-1}\right)$, followed by a maximum average $I$ after Day $6\left(105.3 \times 10^{-4} \mu g \mathrm{C}\right.$ core $\left.^{-1}\right)$. Again, differences between incubation times were not significant.

\section{DISCUSSION}

\section{Natural $\delta^{13} \mathrm{C}$ : nematode and sedimentary organic carbon}

At Stn $\mathrm{AA}, \delta^{13} \mathrm{C}_{\text {sed }}$ values lay within the range of depleted $\delta^{13} \mathrm{C}$ values reported for the high latitude Southern Ocean (Wada et al. 1987, Moens et al. 2007). Fluctuations of isotopic values in the food web can be caused by variation of ${ }^{13} \mathrm{C}$ contents in the phytoplankton thriving within a narrow range of temperature and $\mathrm{pCO}_{2}$ conditions during the summer season (Handa et al. 1992). Thus, upwelling of ${ }^{13} \mathrm{C}$ depleted waters at the Antarctic Divergence and the high solubility of $\mathrm{CO}_{2}$ in the cold Southern Ocean can cause depleted $\delta^{13} \mathrm{C}$ signals (Archambeau et al. 1998). Fischer (1991) and Rau et al. (1991) reported very light plankton $\delta^{13} \mathrm{C}$ values $(-24.0$ to $-30.0 \%$ ) for the Atlantic sector of the Southern Ocean and the Weddell Sea, whilst for the southeastern Weddell Sea region, Abelmann \& Gersonde (1991) reported average $\delta^{13} \mathrm{C}$ signals of $-24.2 \%$ in sedimentation pulses of sinking neritic diatoms and krill faecal strings.A large part of the diatom production in the euphotic zone often ends up sinking to the seafloor in the form of intact cells or empty frustules (Tremblay et al. 2006), and even in faecal strings, phytoplankton cells can remain undigested or undergo only limited degradation (Bathmann et al. 1991). High chl a content and 'freshness' of OM in sediments at Stn AA (Table 1) indicate that there is a high contribution of fresh phytoplankton to the sedimentary OM. The typically depleted signals of sinking aggregates of diatoms and/or diatom-derived detritus in the Antarctic correspond well with the average natural $\delta^{13} \mathrm{C}_{\text {sed }}$ value at Stn AA $(-25.2 \pm 0.1 \%$ o), and together with the chl a content and freshness of OM, suggest that a mixture of 'fresh' phytoplankton-derived matter and more ${ }^{13} \mathrm{C}$ depleted detritus determines the deep-sea benthic food supply in this case. Any major contribution of sea-ice algae at Stn AA was probably limited, since sea-ice algae typically have heavier $\delta^{13} \mathrm{C}$ signals ( -18 to $-20 \%$ ) (Wada et 

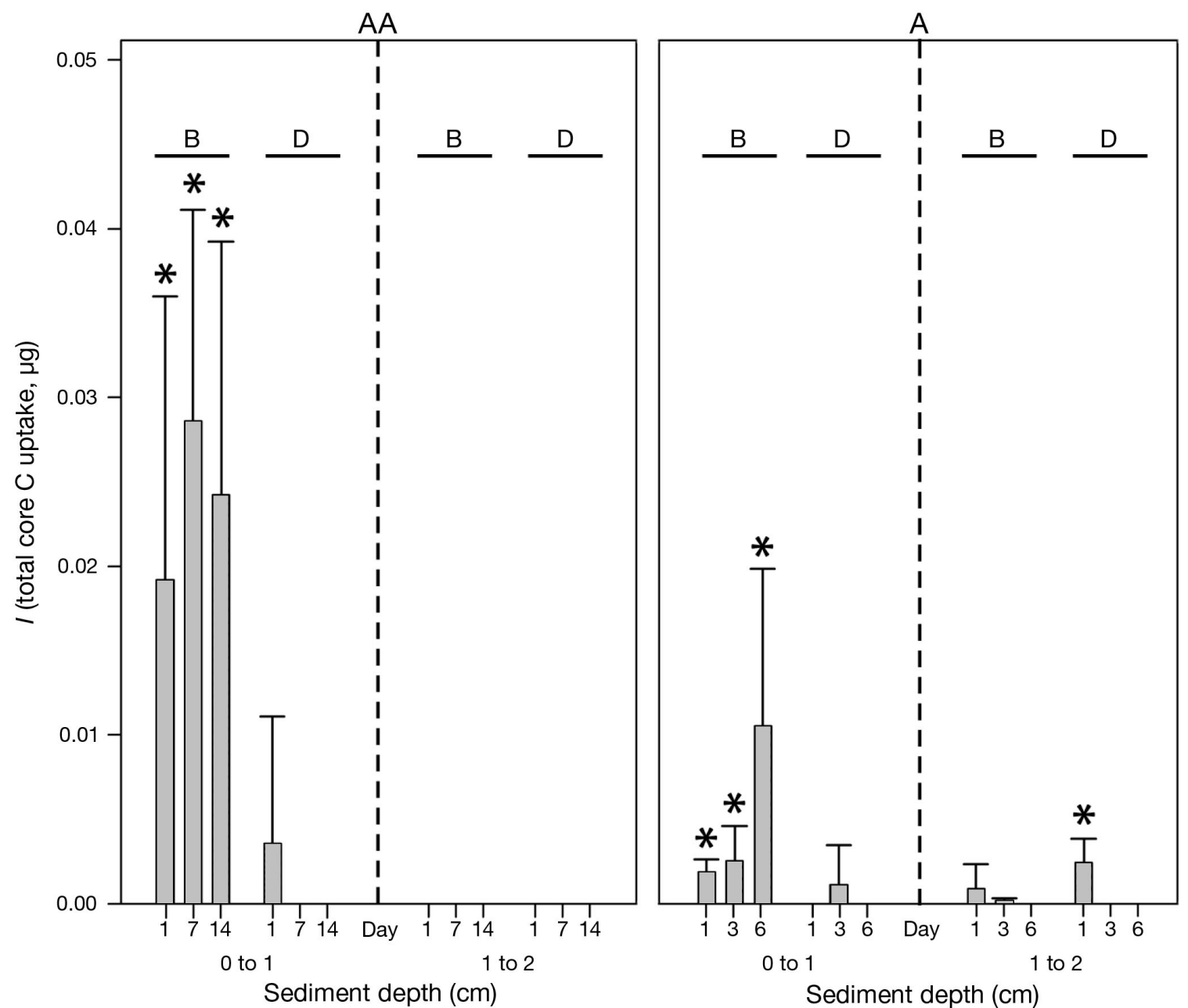

Fig. 4. Total core carbon uptake $(I)$ by the nematode community during the experiments. B: bacteria treatments; D: diatom treatments; AA: Antarctic station, Kapp Norvegia; A: Arctic station, Hausgarten; all bars denote mean $\pm \mathrm{SD}\left({ }^{*}\right)$ indicates significant $\delta^{13} \mathrm{C}$ difference $(\mathrm{p}<0.05)$ compared with background values

al. 1987, Fischer et al. 1988, Bathmann et al. 1991, Tamelander et al. 2008).

In the Arctic, phytoplankton production and downward flux of OM is heavily dependent on variable ice conditions and timing and intensity of phytoplankton blooms (Wassmann 1998). Tamelander et al. (2008) reported a range of $\delta^{13} \mathrm{C}$ signatures of suspended OM $(-28.3$ to $-20.2 \%)$ for the Arctic Barents Sea and found that the majority of OM exported from the euphotic zone was derived from pelagic primary production (mean, $-24.3 \%$ ). However, at some stations, the icealgal signal $(-20.0 \%)$ dominated the isotopic composition of sinking particulate OM. Taking into account the relatively enriched $\delta^{13} \mathrm{C}_{\text {sed }}$ values at Stn $\mathrm{A}-22.4 \%$ ), sea-ice algae may have substantially contributed to OM deposition in these sediments. However, near-zero chl a concentrations and 'freshness' values of the sedimentary $\mathrm{OM}$ at this station (Table 1) contradict the idea that there was a major recent input of fresh algal detritus; however, this contradicts the observations made by Hoste et al. (2007) at the same location as the present study during a $5 \mathrm{yr}$ period. Sediment bound chl $a$ attained much higher levels than observed in the present study. A possible explanation may be the presence of megafauna at the Hausgarten site (2432 to $2629 \mathrm{~m}$ ), dominated by holothurians (Soltwedel et al. 2009), which may have removed high quality phytodetrital material settling on the sea floor before the experiment, as was reported by Bett et al. (2001) and Ginger et al. (2001) for the Porcupine Abyssal Plain (northeastern Atlantic Ocean). The megafaunal removal of high quality phytodetrital material reported for the Porcupine Abyssal Plain was considered to be, at least partially, the result of anomalously high numbers of holothurians sifting through the sediments for high-quality, freshly arrived, phytodetrital material 
(Bett et al. 2001, Ginger et al. 2001). The megafauna at the Hausgarten attain lower densities than at the Porcupine Abyssal Plain (Soltwedel et al. 2009), but a comparable effect is not unlikely. As such, the relatively high sedimentary total organic carbon (TOC) content, low chl a concentration and heavy $\delta^{13} \mathrm{C}_{\text {sed }}$ values indicate a large, but generally low-quality, availability of OM, at least in part derived from older inputs of ice algae. Alternatively, benthic bacteria may be a major contributor to the sediment's TOC pool as has been observed for deep-sea sediments (Witte et al. 2003b). Benthic bacteria can play a significant role in the modification of the $\delta^{13} \mathrm{C}$ value of the sedimentary detritus and are considered important in short-term deep-sea benthic responses to phytodetritus (Moodley et al. 2002). By recycling OM, bacteria provide a pathway for refractory and/or indigestible detritus to enter the metazoan food web. As well as benthic bacterial production, microbial reworking of primary produced $\mathrm{OM}$ in the water column may also contribute to the sediment's C isotopic signature. Specific lipid studies from the Arctic Ocean have indicated that OM reaching the benthos comprises a significant bacterial component (Birgel et al. 2004).

At both Stns AA and A, the seasonal variation in seaice coverage exerts considerable control on the meiobenthos (Vanhove et al. 1999, Hoste et al. 2007), and nematode diet may vary considerably during the year, depending on the variability of OM influx and type and availability of food sources. The top centimetre of the sediment at Stn AA was characterised by variable $\delta^{13} C_{\text {nema }}$ values (-19.1 to $-23.2 \%$ ), which suggests that a combination of ice algae, bacteria and sinking aggregates of phytoplankton are used as food sources. The variability of $\delta^{13} C_{\text {nema }}$ values in the 1 to $2 \mathrm{~cm}$ layer and the offset between $\delta^{13} \mathrm{C}_{\text {nema }}$ and $\delta^{13} \mathrm{C}_{\text {sed }}$ were both smaller than at the sediment surface (Fig. 3), indicating that nematodes at the sediment surface feed more selectively on the available TOC. This supports the idea that nematodes at or near the sediment surface primarily use fresh, high quality OM, whereas nematodes in deeper strata rely on older, more refractory OM (Rudnick et al. 1985, Olafsson et al. 1999).

At $\operatorname{Stn} A$, the relatively enriched $\delta^{13} C_{\text {nema }}$ values $(-18.8 \pm 0.5 \%)$ and minimal chloroplastic pigment concentrations suggest that bacteria, characterised by similarly enriched $\delta^{13} \mathrm{C}$ signatures, form the principal nematode food source. Breakdown of detritus by benthic bacteria at the sediment-water interface modifies the value of the freshly settled material and provides a pathway through which the OM is made available to higher trophic levels. When phytodetritus arrives at the deep-sea floor, it can be used rapidly by adapted bacterial populations (Lochte \& Turley 1988) and preferential removal of enriched ${ }^{13} \mathrm{C}$ compounds by microbial degradation would lead not only to a decrease in the $\delta^{13} \mathrm{C}$ value of the residual OM (Lehmann et al. 2002), but also to bacterial cells that are generally enriched in ${ }^{13} \mathrm{C}$ relative to the substrate (Macko \& Estep 1984). A high bacterial biomass, relative to the total TOC pool, as a result of phytodetrital input may, therefore, lead to enriched sediment values. This could particularly be the case in deep-sea environments where microbial biomass usually dominates total benthic biomass, such as the Porcupine Abyssal Plain ( 95\%, Witte et al. 2003b). Also the TOC pool in Arctic sediments may be dominated by bacteria, as suggested by the high TOC content but virtual absence of chl a indicating a lack of phytoplanktonic input from the euphotic zone. $\delta^{13} \mathrm{C}_{\text {sed }}$ enrichments at the sediment-water interface of up to 3 to $4 \%$ have been found (Fischer 1989). Such enrichment values correspond to the offset observed between the $\delta^{13} C_{\text {nema }}$ and $\delta^{13} C_{\text {sed }}$ values at $\operatorname{Stn} A$, which suggests that benthic bacteria contribute to the nematode community. Alternatively, as mentioned earlier, pelagic bacterial reworking of primary produced OM may significantly contribute to the sediment TOC pool.

For both Stns AA and $\mathrm{A}$, the ${ }^{13} \mathrm{C}$ isotopic difference between the nematode community and the sedimentary OC $\left(\Delta \delta^{13} C_{\text {nema-sed }}\right)$ provides an indication of selective feeding. Higher $\Delta \delta^{13} C_{\text {nema-sed values indicate that }}$ specific food sources from within the bulk TOC pool are selectively used. In the present study, such isotopic shift averaged $+3.2 \pm 0.8 \%$ (Fig. 3 ) and parallels isotopic shifts found by Fischer (1989) as a result of bacterial reworking of benthic OC. Based on stable isotope data, Goering et al. (1990) and Iken et al. (2001) previously suggested that deep-sea nematodes feed on nanobiotic fungi and bacteria and our data largely support this idea. Thus, it seems that polar deep-sea nematodes might not directly depend on settled phytodetrital matter, but use bacteria or fungi growing on that detritus. Greater ${ }^{13} \mathrm{C}$ enrichment of nematodes due to the assimilation of resuspended and microbially reworked OM was also suggested by Hobson et al. (1995) for an Arctic polynia food web.

The attempts of the present study to reveal potential food sources by means of natural isotopes should be regarded with some caution as the $\delta^{13} C_{\text {nema }}$ values presented here represent the community as a whole (based on an average of 70 nematode individuals). Therefore, presence of different feeding guilds and nematode genera may well have influenced the $\delta^{13} \mathrm{C}_{\text {nema }}$ value of the community. Thus, selectivity for food sources within the community will result in a $\delta^{13} \mathrm{C}_{\text {nema }}$ signal that reflects the assimilation and/or uptake of a combination of different food sources. Some of the variability between replicates at a single 
station may, for instance, be related to the presence or absence of few individuals of large-bodied species with specific feeding habits (Moens et al. 2005).

\section{Pulse-chase experiments}

At both stations, significant uptake of labelled food sources only occurred at the sediment surface and only in response to the $\mathrm{OM}$ of bacterial origin. A consistent response to the fresh input of diatom carbon could not be distinguished, nor did nematodes deeper in the sediment show any real signs of label uptake. The fact that only surface nematodes responded to settling OM input supports the idea that freshly settled matter is used by surface nematodes, while subsurface nematodes feed predominantly on a more stable, buried 'reservoir' of detritus and associated bacteria (Rudnick 1989). Alternatively, isolation of the cores in a laboratory environment, without natural pore water flushing, and absence of macrofaunal activity and hence low mixing rates, probably reduced ${ }^{13} \mathrm{C}$ penetration into the subsurface layers and, thus, its availability to subsurface nematodes. In addition to this, sufficient food may have already been present to sustain the nematode community, especially since the experiments were performed in late summer after the intensive bloom, which made the experimental addition of extra food sources redundant for their energy requirements. This is supported by very low uptake rates of the surface nematodes in both experiments. Another possible reason that contributed to an attenuated nematode response to the labelled food sources may have been caused by the process of freeze-drying the labelled food sources. Although many pulse-chase experiments documented in the literature have been conducted with the aid of freeze-dried labelled food sources, preliminary results (M. De Troch unpubl. data) show that in comparison with freshly cultivated food, the addition of less fresh, freeze-dried material may evoke a lower meiofauna response. However, the significance of the resulting difference in carbon uptake by the meiofauna community is still in need of validation.

At Stn AA the nematode community responded immediately to the added bacterial food source with total core uptake averaging $19.19 \times 10^{-3} \mu \mathrm{g} \mathrm{C}$ after $1 \mathrm{~d}$ and showed no significant increase or decrease thereafter (Fig. 4). Hitherto, only meiofauna responses to phytoplanktonic food pulses have been assessed (Moodley et al. 2002, Witte et al. 2003b, Moens et al. 2007). These studies showed either a minimal uptake response of metazoan meiofauna (nematodes) to the food pulse and/or indicated a significant time lag before the added label was incorporated. No such time lag was observed in our experiment at Stn AA. However, notwithstand- ing the rapid response observed in the present study, total uptake by the nematode community remained very low and only a minor fraction of the added ${ }^{13} \mathrm{C}$ became assimilated or ingested. The experimental addition of $1000 \mathrm{mg} \mathrm{C} \mathrm{m}^{-2}$ to the cores corresponds to $\leq 1 \%$ of the OC already present in the sediments, and hence, represents a very small amount of carbon compared with the TOC pool. However, this does not mean that the remaining $99 \%$ or more is available to the nematode community. Nematodes feed selectively and a large portion of the sedimentary carbon may never be used because it is of poor nutritional quality or simply because it is not the right food source. Nevertheless, if we assume a similar benthic carbon mineralisation rate as observed by Moens et al. (2007) for the Bransfield Strait, then the nematode community uptake of the added carbon at Stn AA is comparable with $<0.02 \%$ of total benthic carbon mineralisation values. This is probably a substantial underestimate, because the tissue inventory of ${ }^{13} \mathrm{C}$ mainly reflects carbon incorporated into somatic tissue and, hence, does not include carbon that has been processed and lost (e.g. through defecation and respiration, Moens et al. 1999). However, even taking such an underestimate into account, it is clear that the nematode assemblage at Stn AA contributed $<1 \%$ to mineralisation of the experimentally added carbon, which agrees with the Bransfield Strait experiment (Moens et al. 2007).

The nematodes at Stn A showed a less intense response, with uptake occurring more gradually, and a relatively large, but nonsignificant increase evident between Day 3 and 6 . This slightly delayed uptake may suggest either that the bacterial OM entered the nematodes indirectly, e.g. through feeding on live bacteria that in turn had used the added bacterial carbon, or that the nematodes in these Arctic sediments show a slower response to input of fresh carbon. In general, the carbon uptake kinetics observed at Stn A correspond with results from literature for shallow water (Herman et al. 2000, van Oevelen et al. 2006) and deep-sea environments (Blair et al. 1996, Gooday et al. 1996, Levin et al. 1999, Moodley et al. 2002, Witte et al. 2003b).

At both stations, consistent significant uptake of diatom label did not occur, suggesting that nematodes were unable to consume Thalassiosira rotula cells, or that sufficient and/or more accessible food was already present in the sediments before incubation. Although relatively small nematodes may have difficulty consuming large diatom cells (Olafsson et al. 1999), consumption of $T$. rotula cells with an average size of $8 \mu \mathrm{m}$ by small diatom-feeding nematodes should not be precluded. In addition, $T$. rotula was successfully used in situ by Witte et al. (2003b) to simulate a phytodetritus pulse to the abyssal floor. In their experiments, signifi- 
cant uptake by nematodes was observed within $2.5 \mathrm{~d}$ with a maximum uptake after $23 \mathrm{~d}$ (ca. $0.04 \%$ uptake of total added ${ }^{13} \mathrm{C}_{i}$ recalculated from Witte et al. 2003b). Although this quick response does not exclude microbial reworking of the labelled diatoms before nematode use (which would be supported by their bacterial ${ }^{13} \mathrm{C}$-incorporation results), it strongly suggests a direct consumption of $T$. rotula by at least part of the nematode community. It seems most probable that there was already abundant or more accessible food available before the experiment, as partially indicated by TOC and chl a values. The use of labelled sources other than T. rotula (e.g. cyanobacteria, other diatom species) in different deep-sea experiments resulted in uptake kinetics for the nematode community comparable with the present study (Moodley et al. 2002, Moens et al. 2007). However, the answer to the question, which food to label? remains equivocal without further knowledge on specific nematode food preferences such as documented by Moens \& Vincx (1997) and Olafsson et al. (1999) among others.

\section{CONCLUSIONS}

The uptake by the nematode community of ${ }^{13} \mathrm{C}$ labelled bacteria in the tracer experiments, as opposed to freshly settled phytodetritus, suggests a preference for bacterial carbon by nematodes in polar slope regions. In combination with natural stable ${ }^{13} \mathrm{C}$ isotope signals, these results hint that microbial activity could provide a trophic pathway through which carbon that is left unused by the metazoans may enter the traditional metazoan food web compartments. Considering that nematodes form the most abundant taxon of deepsea metazoans, high rates of microbial reworking of organic matter and close bacteria-nematode interaction could enhance C flow in deep-sea food webs. However, very low uptake rates of the experimentally added carbon by the nematode community suggest a limited contribution to total carbon mineralisation of freshly deposited OM. Conversely, in the absence of adequate information on nematode energy budgets, it is unclear to what extent the measured carbon absorption rates in our pulse-chase experiment can meet the nematodes' energetic requirements.

In addition to this, the consistent ${ }^{13} \mathrm{C}$ isotopic offset between the sedimentary bulk OM and the nematode community suggests that nematodes selectively use specific components of the available food, especially at the sediment surface. In the present study, we concentrated on the total nematode community rather than using different feeding guilds or genera to assess carbon uptake dynamics, which could significantly increase our knowledge.
Acknowledgements. We are very much indebted to the Alfred-Wegener Institute for Polar and Marine Research and the captain and crew members of the RV 'Polarstern' as well as IFREMER and captain and crew of the RV 'l'Atalante'. Also scientific crew members are greatly acknowledged for their support with sampling; special thanks goes to E. Fahrbach and A. Brandt, the leading scientists during the Antarctic cruise. Furthermore, we thank Dr. M. Vincx for the use of research facilities. This research was performed under the auspices of the Scientific Research Programme on Antarctica from the Belgian Science Policy (BIANZO), the HERMES project (EC contract GOCE511234, funded by the European Commission's Sixth Framework Programme), and the concerted actions of Ghent University (GOA 01GZ0705).

\section{LITERATURE CITED}

Abelmann A, Gersonde R (1991) Biosiliceous particle flux in the Southern Ocean. Mar Chem 35:503-536

Archambeau AS, Pierre C, Poisson A, Schauer B (1998) Distributions of oxygen and carbon stable isotopes and CFC-12 in the water masses of the Southern Ocean at 30 degrees E from South Africa to Antarctica: results of the CIVA1 cruise. J Mar Syst 17:25-38

Barnett PRO, Watson J, Connelly D (1986) A multiple corer for taking virtually undisturbed samples from shelf, bathyal and abyssal sediments. Proc R Soc Lond B Biol Sci 88: 304-305

> Bathmann U, Fischer G, Muller PJ, Gerdes D (1991) Shortterm variations in particulate matter sedimentation off Kapp Norvegia, Weddell Sea, Antarctica: relation to water mass advection, ice cover, plankton biomass and feeding activity. Polar Biol 11:185-195

Bathmann UV, Scharek R, Klaas C, Dubischar CD, Smetacek V (1997) Spring development of phytoplankton biomass and composition in major water masses of the Atlantic sector of the Southern Ocean. Deep-Sea Res II 44:51-67

> Bauerfeind E, Nöthig EM, Beszczynska A, Fahl K and others (2009) Particle sedimentation patterns in the eastern Fram Strait during 2000-2005: results from the Arctic long-term observatory HAUSGARTEN. Deep-Sea Res I 56:1471-1487

Bett BJ, Malzone MG, Narayanaswamy BE, Wigham BD (2001) Temporal variability in phytodetritus and megabenthic activity at the seabed in the deep Northeast Atlantic. Prog Oceanogr 50:349-368

> Birgel D, Stein R, Hefter J (2004) Aliphatic lipids in recent sediments of the Fram Strait/Yermak Plateau (Arctic Ocean): composition, sources and transport processes. Mar Chem 88:127-160

Blair NE, Levin LA, DeMaster DJ, Plaia G (1996) The shortterm fate of fresh algal carbon in continental slope sediments. Limnol Oceanogr 41:1208-1219

Bodungen Bv, Smetacek VS, Tilzer MM, Zeitzschel B (1986) Primary production and sedimentation during spring in the Antarctic Peninsula region. Deep-Sea Res 33: $177-194$

Carman KR, Fry B (2002) Small-sample methods for $\delta^{13} \mathrm{C}$ and $\delta^{15} \mathrm{~N}$ analysis of the diets of marsh meiofaunal species using natural-abundance and tracer-addition isotope techniques. Mar Ecol Prog Ser 240:85-92

Cota GF, Kottmeier ST, Robinson DH, Smith WO, Sullivan CW (1990) Bacterioplankton in the marginal ice-zone of the Weddell Sea: biomass, production and metabolic activities during austral autumn. Deep-Sea Res Part A 37: 1145-1167 
Craig H (1957) Isotopic standards for carbon and oxygen and correction factors for mass-spectrometric analysis of carbon dioxide. Geochim Cosmochim Acta 12:133-149

> Danovaro R, Dell'Anno A, Martorano D, Parodi P, Marrale ND, Fabiano M (1999a) Seasonal variation in the biochemical composition of deep-sea nematodes: bioenergetic and methodological considerations. Mar Ecol Prog Ser 179: 273-283

Danovaro R, Dinet A, Duineveld G, Tselepides A (1999b) Benthic response to particulate fluxes in different trophic environments: a comparison between the Gulf of Lions-Catalan Sea (western-Mediterranean) and the Cretan Sea (eastern-Mediterranean). Prog Oceanogr 44: 287-312

Emerson SR, Hedges JI (2008) Chemical oceanography and the marine carbon cycle. Cambridge University Press, Cambridge

Fahrbach E (ed) (2006) The expedition ANTARKTIS-XXII/3 of the research vessel 'Polarstern' in 2005 with contributions of the participants. Ber Polarforsch Meeresforsch 533. Alfred Wegener Institute for Polar and Marine Research, Bremerhaven

Fischer G (1989) Stabile Kohlenstoff-Isotope in partikulärer organischer Substanz aus dem Südpolarmeer (atlantischer Sektor), Vol 5. Ber Fachber Geowiss. University of Bremen, Bremen

Fischer G (1991) Stable carbon isotope ratios of plankton carbon and sinking organic matter from the Atlantic sector of the Southern Ocean. Mar Chem 35:581-596

> Fischer G, Fütterer D, Gersonde R, Honjo S, Ostermann D, Wefer G (1988) Seasonal variability of particle flux in the Weddell Sea and its relation to ice cover. Nature 335: $426-428$

Fogg GE (1998) The biology of polar habitats. Oxford University Press, Oxford

> Ginger ML, Billett DSM, Mackenzie KL, Konstandinos K and others (2001) Organic matter assimilation and selective feeding by holothurians in the deep sea: some observations and comments. Prog Oceanogr 50:407-421

Goering J, Alexander V, Haubenstock N (1990) Seasonal variability of stable carbon and nitrogen isotope ratios of organisms in a North Pacific bay. Estuar Coast Shelf Sci 30:239-260

Gooday AJ (2002) Biological responses to seasonally varying fluxes of organic matter to the ocean floor: a review. J Oceanogr 58:305-332

Gooday AJ, Pfannkuche O, Lambshead PJD (1996) An apparent lack of response by metazoan meiofauna to phytodetritus deposition in the bathyal north-eastern Atlantic. J Mar Biol Assoc UK 76:297-310

Graf G (1989) Benthic pelagic coupling in a deep-sea benthic community. Nature 341:437-439

> Graf G, Gerlach SA, Ritzrau W, Scheltz A and others (1995) Benthic-pelagic coupling in the Greenland-Norwegian Sea and its effect on the geological record. Geol Rundsch 84:49-58

Guillard RRL (1975) Culture of phytoplankton for feeding marine invertebrates. In: Smith WL, Chanley MH (eds) Culture of marine invertebrate animals. Plenum Press, New York, p 29-60

Handa N, Nakatsuka T, Fukuchi M, Hattori H, Hoshiai T (1992) Vertical fluxes and ecological significance of organic materials during the phytoplankton bloom during austral summer in Breid Bay, Antarctica. Mar Biol 112: $469-478$

Heip C, Vincx M, Vranken G (1985) The ecology of marine nematodes. Oceanogr Mar Biol Annu Rev 23:399-489
Herman PMJ, Middelburg JJ, Widdows J, Lucas CH, Heip CHR (2000) Stable isotopes as trophic tracers: combining field sampling and manipulative labelling of food resources for macrobenthos. Mar Ecol Prog Ser 204:79-92

> Herman RL, Dahms HU (1992) Meiofauna communities along a depth transect off Halley Bay (Weddell Sea-Antarctica). Polar Biol 12:313-320

Higgins RP, Thiel H (1988) Introduction to the study of meiofauna. Smithsonian Institution Press, London

Hobson KA, Ambrose WG Jr, Renaud PE (1995) Sources of primary production, benthic-pelagic coupling, and trophic relationships within the Northeast Water Polynya: Insights from delta ${ }^{13} \mathrm{C}$ and delta ${ }^{15} \mathrm{~N}$ analysis. Mar Ecol Prog Ser 128:1-10

Hoste E, Vanhove S, Schewe I, Soltwedel T, Vanreusel A (2007) Spatial and temporal variations in deep-sea meiofauna assemblages in the Marginal Ice Zone of the Arctic Ocean. Deep-Sea Res I 54:109-129

Iken K, Brey T, Wand U, Voigt J, Junghans P (2001) Food web structure of the benthic community at the Porcupine Abyssal Plain (NE Atlantic): a stable isotope analysis. Prog Oceanogr 50:383-405

Jensen P (1987) Feeding ecology of free-living aquatic nematodes. Mar Ecol Prog Ser 35:187-196

- Karl DM, Novitsky JA (1988) Dynamics of microbial growth in surface layers of a coastal marine sediment ecosystem. Mar Ecol Prog Ser 50:169-176

Killops SD, Killops VJ (2005) Introduction to organic geochemistry. Blackwell Publishing, Oxford

Lehmann MF, Bernasconi SM, Barbieri A, McKenzie JA (2002) Preservation of organic matter and alteration of its carbon and nitrogen isotope composition during simulated and in situ early sedimentary diagenesis. Geochim Cosmochim Acta 66:3573-3584

Levin LA (1991) Interactions between metazoans and large agglutinating protozoans: implications for the community structure of deep-sea benthos. Integr Comp Biol 31:886-900

> Levin LA, Blair NE, Martin CM, DeMaster DJ, Plaia G, Thomas CJ (1999) Macrofaunal processing of phytodetritus at two sites on the Carolina margin: in situ experiments using ${ }^{13}$ C-labeled diatoms. Mar Ecol Prog Ser 182:37-54

Lochte K, Turley CM (1988) Bacteria and cyanobacteria associated with phytodetritus in the deep sea. Nature 333: 67-69

> Macko SA, Estep MLF (1984) Microbial alteration of stable nitrogen and carbon isotopic compositions of organic matter. Org Geochem 6:787-790

> Moens T, Vincx M (1997) Observations on the feeding ecology of estuarine nematodes. J Mar Biol Assoc UK 77: 211-227

Moens T, Vincx M (1998) On the cultivation of free-living marine and estuarine nematodes. Helgol Meersunters 52: 115-139

> Moens T, Verbeeck L, de Maeyer A, Swings J, Vincx M (1999) Selective attraction of marine bacterivorous nematodes to their bacterial food. Mar Ecol Prog Ser 176:165-178

> Moens T, Bouillon S, Gallucci F (2005) Dual stable isotope abundances unravel trophic position of estuarine nematodes. J Mar Biol Assoc UK 85:1401-1407

Moens T, Vanhove S, De Mesel I, Kelemen B, Janssens T, Dewicke A, Vanreusel A (2007) Carbon sources of Antarctic nematodes as revealed by natural carbon isotope ratios and a pulse-chase experiment. Polar Biol 31:1-13

> Moodley L, van der Zwaan GJ, Herman P, Kempers L, van Breugel P (1997) Differential response of benthic meiofauna to anoxia with special reference to Foraminifera (Protista: Sarcodina). Mar Ecol Prog Ser 158:151-163 
Moodley L, Middelburg JJ, Boschker HTS, Duineveld GCA, Pel R, Herman PMJ, Heip CHR (2002) Bacteria and Foraminifera: key players in a short-term deep-sea benthic response to phytodetritus. Mar Ecol Prog Ser 236: 23-29

Moodley L, Middelburg JJ, Soetaert K, Boschker HTS, Herman PMJ, Heip CHR (2005) Similar rapid response to phytodetritus deposition in shallow and deep-sea sediments. J Mar Res 63:457-469

Morata N, Renaud PE, Brugel S, Hobson KA, Johnson BJ (2008) Spatial and seasonal variations in the pelagic-benthic coupling of the southeastern Beaufort Sea revealed by sedimentary biomarkers. Mar Ecol Prog Ser 371:47-63

> Novitsky JA (1987) Microbial growth rates and biomass production in a marine sediment: evidence for a very active but mostly non-growing community. Appl Environ Microbiol 53:2368-2372

Olafsson E, Modig H, van de Bund WJ (1999) Species specific uptake of radio-labelled phytodetritus by benthic meiofauna from the Baltic Sea. Mar Ecol Prog Ser 177:63-72

Rau GH, Hopkins TL, Torres JJ (1991) ${ }^{15} \mathrm{~N} /{ }^{14} \mathrm{~N}$ and ${ }^{13} \mathrm{C} /{ }^{12} \mathrm{C}$ in Weddell Sea invertebrates: implications for feeding diversity. Mar Ecol Prog Ser 77:1-6

Rudnick DT (1989) Time lags between the deposition and meiobenthic assimilation of phytodetritus. Mar Ecol Prog Ser 50:231-240

Rudnick DT, Elmgren R, Frithsen JB (1985) Meiofaunal prominence and benthic seasonality in a coastal marine ecosystem. Oecologia 67:157-168

Smith CR, Mincks S, DeMaster DJ (2006) A synthesis of bentho-pelagic coupling on the Antarctic shelf: food banks, ecosystem inertia and global climate change. Deep-Sea Res II 53:875-894

Soltwedel T (2000) Metazoan meiobenthos along continental margins: a review. Prog Oceanogr 46:59-84

Soltwedel T, Jaeckisch N, Ritter N, Hasemann C, Bergmann M, Klages M (2009) Bathymetric patterns of megafaunal assemblages from the arctic deep-sea observatory HAUSGARTEN. Deep-Sea Res I 56:1856-1872

Sullivan CW, Cota GF, Krempin DW, Smith WO (1990) Distribution and activity of bacterioplankton in the marginal ice zone of the Weddell-Scotia Sea during austral spring. Mar Ecol Prog Ser 63:239-252

Tamelander T, Reigstad M, Hop H, Carroll ML, Wassmann P (2008) Pelagic and sympagic contribution of organic matter to zooplankton and vertical export in the Barents Sea marginal ice zone. Deep-Sea Res II 55:2330-2339

Tietjen JH, Lee JJ (1973) Life history and feeding habits of marine nematode, Chromadora macrolaimoides Steiner. Oecologia 12:303-314

Tremblay JE, Hattori H, Michel C, Ringuette $M$ and others (2006) Trophic structure and pathways of biogenic carbon

Editorial responsibility: Hans Heinrich Janssen, Oldendorf/Luhe, Germany flow in the eastern North Water Polynya. Prog Oceanogr 71:402-425

van Oevelen D, Middelburg JJ, Soetaert K, Moodley L (2006) The fate of bacterial carbon in an intertidal sediment: modeling an in situ isotope tracer experiment. Limnol Oceanogr 51:1302-1314

> Vanhove S, Wittoeck J, Desmet G, Vandenberghe B and others (1995) Deep-sea meiofauna communities in Antarctica: structural analysis and relation with the environment. Mar Ecol Prog Ser 127:65-76

Vanhove S, Lee HJ, Beghyn M, Van Gansbeke D, Brockington S, Vincx M (1998) The metazoan meiofauna in its biogeochemical environment: the case of an Antarctic coastal sediment. J Mar Biol Assoc UK 78:411-434

Vanhove S, Arntz W, Vincx M (1999) Comparative study of the nematode communities on the southeastern Weddell Sea shelf and slope (Antarctica). Mar Ecol Prog Ser 181: $237-256$

Vanreusel A, Vincx M, Schram D, Vangansbeke D (1995) On the vertical distribution of the metazoan meiofauna in shelf break and upper slope habitats of the NE Atlantic. Int Rev Gesamten Hydrobiol 80:313-326

Vincx M (1996) Meiofauna in marine and fresh water sediments. In: Hall GS (ed) Methods for the examination of organismal diversity in soils and sediments. CABI, Cambridge University Press, Cambridge, p 214-248

- Wada E, Terazaki M, Kabaya Y, Nemoto T (1987) ${ }^{15} \mathrm{~N}$ and ${ }^{13} \mathrm{C}$ abundances in marine environments with emphasis on biogeochemical structure of food web. Deep-Sea Res 34: 829-841

Wassmann P (1997) Retention versus export food chains: processes controlling sinking loss from marine pelagic systems. Hydrobiologia 363:29-57

Wentworth CK (1922) A scale of grade and class terms for clastic sediments. J Geol 30:377-392

Wieser W (1953) Beziehungen zwischen Mundhöhlengestalt, Ernährungsweise und Vorkommen bei freilebenden marinen Nematoden. Arkiv för Zoologi 2:439-484

> Witte U, Aberle N, Sand M, Wenzhofer F (2003a) Rapid response of a deep-sea benthic community to POM enrichment: an in situ experimental study. Mar Ecol Prog Ser 251:27-36

- Witte U, Wenzhofer F, Sommer S, Boetius A and others (2003b) In situ experimental evidence of the fate of a phytodetritus pulse at the abyssal sea floor. Nature 424: 763-766

Wright SW, Jeffrey SW (1997) High-resolution HPLC system for chlorophylls and carotenoids of marine phytoplankton. In: Jeffrey SW, Mantoura RFC, Wright SW (eds) Phytoplankton pigments in oceanography: guidelines to modern methods, Vol 10. UN Educational, Scientific and Cultural Organization, Paris, p 327-341

Submitted: July 10, 2009; Accepted: February 8, 2010 Proofs received from author(s): April 30, 2010 